\title{
Morphophysiological characteristics of arabic coffee
}

\author{
Lucas Aparecido Manzani LISBOA1;2*, Matheus Luís Oliveira CUNHA², Fernando Takayuki NAKAYAMA³, \\ Paulo Alexandre Monteiro de FIGUEIREDO², Ronaldo da Silva VIANA², \\ Sérgio Bispo RAMOS², Samuel FERRARI ${ }^{2}$
}

\author{
${ }^{1}$ Fundation of Andradina (FEA), Andradina, SP, Brazil. \\ 2São Paulo State University (Unesp), College of Agricultural and Technological Sciences, Dracena, SP, Brazil. \\ 3Paulista Agribusiness Technology Agency (APTA), Alta Paulista Regional Camp, Adamantina, SP, Brazil. \\ *E-mail: lucas.lisboa@unesp.br \\ (ORCID: 0000-0001-9013-232X; 0000-0001-8931-8557; 0000-0002-6405-7685; 0000-0003-4505-6975; \\ 0000-0001-6819-5092; 0000-0002-4406-5792; 0000-0001-8542-204X)
}

Recebido em 02/09/2020; Aceito em 30/12/2020; Publicado em 10/02/2021.

\begin{abstract}
The understanding of the behavior of each cultivar under adverse climatic conditions is important in the choice of plants that best fit the region to be inserted. Due to the large number of cultivars available on the market it makes it difficult for producers to choose which material to plant. In view of the above, this study aimed to know the morphophysiological characteristics of coffee. The experimental design was in randomized blocks with 10 treatments, that is, arabic coffee varieties: Catuai IAC62; Catuai IAC99; Ouro IAC4397; Tupi RN IAC1669-13; Obatã IAC1669-20; Mundo Novo IAC379-24; Mundo Novo IAC 388-17-2; Mundo Novo SH3 Faz São José; Bourbon IACJ15 and Icatu IAC 2944-11 and with four replications totaling 40 plots, where each plot was composed of seven plants. The Mundo Novo IAC 388-17-2 coffee variety shows higher yield in the seventh year of cultivation. Variety of Bourbon IACJ15 coffee presented water use efficiency (EUW) which did not reflect in higher productivity. The Catuai V IAC99 arabica coffee variety stood out in the internal morphology of the leaves. The thickness of the adaxial and abaxial epidermis (TADE and TABE) and the $\mathrm{CO}_{2}$ assimilation rate (A) showed negative correlations with the productivity of processed coffee bags. Keywords: Coffea arabica; plant morphology; plant physiology; varieties.
\end{abstract}

\section{Características morfofisiológicas do café arábico}

RESUMO: O entendimento do comportamento de cada cultivar sob condições climáticas adversas é importante na escolha das plantas que melhor se adaptam à região a ser inserida. Devido ao grande número de cultivares disponíveis no mercado, torna-se difícil para o produtor escolher qual material plantar. Diante do exposto, este estudo teve como objetivo conhecer as características morfofisiológicas do café. O delineamento experimental foi em blocos casualizados com 10 tratamentos, ou seja, variedades de café arábico: Catuai IAC62; Catuai IAC99; Ouro IAC4397; Tupi RN IAC1669-13; Obatã IAC1669-20; Mundo Novo IAC379-24; Mundo Novo IAC 388-17-2; Mundo Novo SH3 Faz São José; Bourbon IACJ15 e Icatu IAC 2944-11 e com quatro repetições totalizando 40 parcelas, sendo cada parcela composta por sete plantas. A variedade de café Mundo Novo IAC 388-17-2 apresenta maior produtividade no sétimo ano de cultivo. A variedade de café Bourbon IACJ15 apresentou eficiência no uso de água (EUW) o que não refletiu em maior produtividade. A variedade de café arábica Catuai V IAC99 se destacou na morfologia interna das folhas. A espessura da epiderme adaxial e abaxial (TADE e TABE) e a taxa de assimilação de $\mathrm{CO}_{2}(\mathrm{~A})$ apresentaram correlações negativas com a produtividade das sacas de café beneficiado.

Keywords: Coffea arabica; morfologia vegetal; fisiologia vegetal; variedades.

\section{INTRODUCTION}

Brazil is one of the world's largest producers of coffee (Coffea Arabica L.), reaching about 30\% of world production, with approximately 2 million hectares planted in 2014 (AGRIANUAL, 2015). Only in the New High Paulista region coffee cultivation was present in five thousand hectares and approximately 65 thousand tons of grain were produced (SANTOS et al., 2015). The national coffee park is made up of $84 \%$ of the Coffea arabica species, accounting for $2.7 \%$ of the total value of Brazilian exports (PINOTTI et al., 2009). The importance of the coffee crop is evident, mainly because of the extension of the cultivated area, the use of labor, the generation of income in the properties, the foreign exchange in the export (RENA et al., 1986).
As coffee cultivation presents an enormous variability of climate, spacing, variety and nutritional, phytosanitary and cultural management, it is recommended that it be carefully applied and even analyzed under the aspect of seedling survival (SANTINATO et al., 2008). The understanding of the behavior of each cultivar under adverse climatic conditions is important in the choice of plants that best fit the region to be inserted. Due to the large number of cultivars available on the market it makes it difficult for producers to choose which material to plant.

Research that evaluates the physiological aspects together with the agronomic aspects of coffee help in the discovery of cultivars with characteristics of tolerance to environmental stresses, pathogens, among others, in addition to assisting in 
the exploration of a greater number of genotypes in coffee breeding programs (QUEIROZ-VOLTAN et al., 2014).

Leaf anatomy is directly influenced by environmental factors, with the status of water in the plant being one of the most important factors of leaf growth; therefore, leaf morphology is a fundamental issue for agricultural production (CASTRO et al., 2009). In view of the above, this study aimed to know the morphophysiological characteristics of coffee.

\section{MATERIAL AND METHODS}

\subsection{Characteristics of the experimental area}

In April of 2011 an experiment was installed in the Paulista Agribusiness Technology Agency, Regional Paulista Regional Camp, located in the municipality of Adamantina, State of São Paulo, with the following geographic coordinates: $21^{\circ} 40^{\prime} 24.024$ "S and $51^{\circ} 8^{\prime} 31.088^{\prime \prime} \mathrm{W}$, with an approximate altitude of $420 \mathrm{~m}$. The climate of the region is characterized as Aw according to Köppen and Geiger, with rainy summer and dry winter, with an average temperature of $22.1^{\circ} \mathrm{C}$ and a rainfall of $1204 \mathrm{~mm}$ per year.

The soil of the area was classified as Argissolo vermelhoamarelo distrófico (EMBRAPA, 2013) with good drainage and presented the chemical attributes according to Table 1.

Dolomitic limestone was applied in total area and the planting was carried out after 15 days of its application, the fertilization of planting was according to Raij et al. (1996).

\subsection{Experimental design}

The experimental design was in randomized blocks with 10 treatments, that is, arabic coffee varieties: Catuai IAC62; Catuai IAC99; Ouro IAC4397; Tupi RN IAC1669-13; Obatã IAC1669-20; Mundo Novo IAC379-24; Mundo Novo IAC 388-17-2; Mundo Novo SH3; Bourbon IACJ15 and Icatu IAC 2944-11 and with four replications totaling 40 plots, where each plot was composed of three plants. The planting spacing of the seedlings was $0.90 \times 3.0 \mathrm{~m}$, making 3703 seedlings per hectare.

Table 1: Chemical attributes of the soil of the area of experiment in moment of the planting.

Tabela 1: Atributos químicos do solo da área de experimento no momento do plantio.

\begin{tabular}{|c|c|c|c|c|c|c|c|c|c|c|c|}
\hline $\mathrm{pH}$ & $\mathrm{OM}$ & $\mathrm{P}$ & $\mathrm{K}$ & $\mathrm{Ca}$ & $\mathrm{Mg}$ & $\mathrm{H}+\mathrm{Al}$ & $\mathrm{Al}$ & SB & CEC & $\mathrm{V} \%$ & $\mathrm{~m} \%$ \\
\hline $\mathrm{CaCl}_{2}$ & $\mathrm{~g} \mathrm{dm}^{-3}$ & $\mathrm{mg} \mathrm{dm}^{-3}$ & & 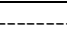 & ----- & --------- & $\mathrm{nmol}_{\mathrm{c}}$ & $\mathrm{n}^{-3}--$ & ------" & - & ---- \\
\hline 4.6 & 12.0 & 26.0 & 2.9 & 8.0 & 4.0 & 20.0 & 1.0 & 14.9 & 34.9 & 43.0 & 6.0 \\
\hline
\end{tabular}

OM: organic matter; SB: Sum of bases; CEC: Cation exchange capacity; V\%: Base saturation; $\mathrm{m} \%$ : Aluminum saturation.

\subsection{Parameters evaluated}

\subsubsection{Yield of grains benefited}

After seven years after planting coffee, the yield of grains benefited, where the fruits were harvested in cherry stage in seven plants of each plot and later, the conversion to the productivity in bags of $60 \mathrm{~kg}$ of coffee benefited per hectare was carried out, where the following formula was used described by Mendes (1994):

$$
\text { YGB }=\frac{\left[\left(\frac{\mathrm{kg}}{\text { plant }} * 0,2\right) * \mathrm{n} \frac{\mathrm{oplant}}{\mathrm{ha}}\right]}{60 \mathrm{~kg}}
$$

where: $\mathrm{YGB}=$ Yield of grains benefited in bags of $60 \mathrm{~kg}$.

\subsubsection{Gas Exchange Parameters}

After seven years the following parameters were determined, gas exchange was evaluated via non-destructive analyses using a portable gas exchange device (Infra-Red Gas Analyzer - IRGA, brand ADC BioScientific Ltd, model LCPro). The following parameters were determined: $\mathrm{CO}_{2}$ assimilation rate expressed by area $\left(\mathrm{A}-\mu \mathrm{mol} \mathrm{CO}_{2} \mathrm{~m}^{-2} \mathrm{~s}^{-1}\right)$, transpiration $\left(\mathrm{E}-\mathrm{mmol} \mathrm{H}_{2} \mathrm{O} \mathrm{m}^{-2} \mathrm{~s}^{-1}\right)$, stomatal conductance ( $\mathrm{gs}-\mathrm{mol} \mathrm{H}_{2} \mathrm{O} \mathrm{m}^{-2} \mathrm{~s}^{-1}$ ), and internal $\mathrm{CO}_{2}$ concentration in the substomatal chamber $\left(\mathrm{Ci}-\mu \mathrm{mol} \mathrm{mol}{ }^{-1}\right)$ and use of water $(\mathrm{EUW})$, determined by the formula: $\mathrm{EUW}=\mathrm{A} / \mathrm{E}(\mu \mathrm{mol} \mathrm{CO} 2$ $\left.\mathrm{m}^{-2} \mathrm{~s}^{-1} / \mathrm{mmol} \mathrm{H}_{2} \mathrm{O} \mathrm{m}^{-2} \mathrm{~s}^{-1}\right)$. The initial conditions imposed

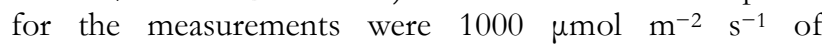
photosynthetically active radiation (PAR), provided by LED lamps, $380 \mathrm{ppm}$ of $\mathrm{CO}_{2}$, and a chamber temperature of 28 ${ }^{\circ} \mathrm{C}$.

\subsubsection{Leaf morphology}

After seven years the following parameters were determined, a leaf fragment was collected from each evaluated plant, the first fully expanded leaf from a branch in the central median region of the plant's crown was chosen., The samples were transported to Laboratory of Vegetal
Morphophysiology and Forages at College of Agricultural and Technological Sciences - São Paulo State University. The collected material was immersed in F.A.A. 70 (formaldehyde $37 \%$, acetic acid and $70 \%$ ethanol in the ratio of 1.0:1.0:18.0 $-\mathrm{V} / \mathrm{V})$. Twenty-four hours after, the fragments were washed and stored in $70 \%$ ethanol until the date of the analyzes, as described by Kraus and Arduim (1997). All fragments of plant tissues were treated with the pertinent procedures for dehydration, diaphanization, inclusion and embedding. By using a microtome Leica that contains steel razors, eight- $\mu \mathrm{m}$ transversal sections were done in each embedded fragment.

The first transversal sections without damage caused by cut of plants tissues was chosen for preparation of the histological slides. These sections were fixed with patches (albumin), were tinted with safranin with a $1 \%$ ratio, and were set in microscope and glass slides wih Entellan ${ }^{\circledR}$ patch (KRAUS and ARDUIN, 1997).

All slides were observed with an Olympus optical microscope; model BX 43, with a attached camera in order to perform the photographs of the cuts. Pictures were used to measure anatomic parameters through the software cellSens Standart that was calibrated with a microscopic ruler in the same gains.

By using transversal sections, the following ultrastructural variables were measured: Phloem Diameter of Leaf (PDL); Xylem Diameter of Leaf (XDL); thickness of adaxial epidermis (TADE) and thickness of abaxial epidermis (TABE) and Thickness of Palisade Parenchyma (PP). Ten measurements were done for all characteristics in each microscope slide. Plots were represented by average value obtained on each characteristic.

\subsection{Statistical analysis}

In all of the datasets considered, the normality of the data was analyzed using the Anderson-Darling test and homoscedasticity was analyzed with the variance equation test (or Levene's test). The results were subjected to statistical 
analysis using Assistat 7.7 static software (SILVA and AZEVEDO, 2016) system for Windows 7.0. The means were compared using the Scott-Knott test $(\mathrm{p}<0.05)$ (BANZATTO and KRONKA, 2013), by using.

\section{RESULTS}

It was observed that the productivity of arabica coffee varieties showed significant differences. The varieties Mundo Novo IAC 388-17-2 showed the highest yield of processed grains, as shown in Table 2.

The evaluation of photosynthesis levels for Arabica coffee varieties (Table 2) indicated that Mundo IAC 388-172 (0.65 mmol CO $\left.\mathrm{m}^{-2} \mathrm{~s}^{-1}\right)$, Mundo Novo SH3 (0.82 mmol $\left.\mathrm{CO}_{2} \mathrm{~m}^{-2} \mathrm{~s}^{-1}\right)$ and Icatu IAC 2944-11 (0.87 mmol CO $\mathrm{m}^{-2}$ $\mathrm{s}^{-1}$ ) had the lowest values observed. It is noted that there was excessive variation in the results evaluated in this characteristic.

It was observed that the internal $\mathrm{CO}_{2}$ concentration varied according to the Arabica coffee varieties in the seventh year after planting (Table 2). The varieties Catuai IAC99 (237.66 $\left.\mu \mathrm{mol} \mathrm{mol}{ }^{-1}\right)$ and Bourbon IACJ15 (218.75 $\mu \mathrm{mol}$ $\mathrm{mol}^{-1}$ ) had the worst results, differing statistically from the other varieties.

Analyzing the transpiration of coffee varieties in the seventh after planting, it is noted that Mundo Novo IAC 38817-2 (2.44 mmol $\left.\mathrm{CO}_{2} \mathrm{~m}^{-2} \mathrm{~s}^{-1}\right)$ had prominence and higher result of this variable when compared to the varieties Obatã IAC 1669-20 (1.36 mmol CO $\left.\mathrm{m}^{-2} \mathrm{~s}^{-1}\right)$, Catuai IAC99 (1.06 $\left.\mathrm{mmol} \mathrm{CO}_{2} \mathrm{~m}^{-2} \mathrm{~s}^{-1}\right)$, Bourbon IACJ15 $\left(0.62 \mathrm{mmol} \mathrm{CO}_{2} \mathrm{~m}^{-2}\right.$ $\left.\mathrm{s}^{-1}\right)$ and Icatu IAC 2944-11 (0.55 $\left.\mathrm{mmol} \mathrm{CO}_{2} \mathrm{~m}^{-2} \mathrm{~s}^{-1}\right)$ as shown in Table 3.

Table 2. Average values of yield of grains benefited (YGB); rate of photosynthesis (A) and internal $\mathrm{CO}_{2}$ concentration in the substomatal chamber (Ci) of arabica coffee varieties.

Tabela 2. Valores médios de rendimento dos grãos beneficiados (YGB); taxa de fotossíntese (A) e concentração interna de $\mathrm{CO}_{2}$ na câmara subestomática $(\mathrm{Ci})$ de variedades de café arábica

\begin{tabular}{|c|c|c|c|}
\hline & $\begin{array}{c}\text { YGB } \\
\text { (bags of } 60 \mathrm{~kg} \text { ) }\end{array}$ & $\begin{array}{c}\mathrm{A} \\
\left(\mu \mathrm{mol} \mathrm{CO} \mathrm{C}^{-2} \mathrm{~s}^{-1}\right)\end{array}$ & $\begin{array}{c}\mathrm{Ci} \\
\left(\mu \mathrm{mol} \mathrm{mol}^{-1}\right) \\
\end{array}$ \\
\hline Catuai IAC62 & $21.98 \mathrm{~d}$ & $2.19 \mathrm{a}$ & $321.25 \mathrm{a}$ \\
\hline Catuai IAC99 & $20.09 \mathrm{~d}$ & $1.82 \mathrm{a}$ & $237.66 \mathrm{~b}$ \\
\hline Ouro IAC4397 & $21.22 \mathrm{~d}$ & $1.83 a$ & $326.41 \mathrm{a}$ \\
\hline Tupi RN IAC1669-13 & $22.66 \mathrm{~d}$ & $1.52 \mathrm{a}$ & $300.33 \mathrm{a}$ \\
\hline Obatã IAC1669-20 & $24.35 \mathrm{~d}$ & $2.02 \mathrm{a}$ & $280.91 \mathrm{a}$ \\
\hline Mundo Novo IAC379-24 & $34.61 \mathrm{c}$ & $2.51 \mathrm{a}$ & $294.75 a$ \\
\hline Mundo Novo IAC 388-17-2 & $58.66 a$ & $0.65 b$ & $294.66 \mathrm{a}$ \\
\hline Mundo Novo SH3 & $32.46 \mathrm{c}$ & $0.82 b$ & $351.41 \mathrm{a}$ \\
\hline Bourbon IACJ15 & $46.19 b$ & $2.02 \mathrm{a}$ & $218.75 b$ \\
\hline Icatu IAC 2944-11 & $40.80 \mathrm{~b}$ & $0.87 \mathrm{~b}$ & $377.83 \mathrm{a}$ \\
\hline $\mathrm{AO}$ & 32.30 & 1.62 & 300.40 \\
\hline $\mathrm{CV}(\%)$ & 22.18 & 27.54 & 27.93 \\
\hline $\mathrm{p}$ value & $<0.0001$ & 0.0164 & 0.0003 \\
\hline
\end{tabular}

AO: Average overall; CV: coefficient of variation.

Table 3. Average values of transpiration (E); stomata conductance (gs) and efficient use of water (EUW) of arabica coffee varieties. Tabela 3. Valores médios de transpiração (E); condutância estomática (gs) e uso eficiente de água (EUW) de variedades de café arábica.

\begin{tabular}{lccc} 
& $\begin{array}{c}\mathrm{E} \\
\left(\mathrm{mmol} \mathrm{H}_{2} \mathrm{O} \mathrm{m}^{-2} \mathrm{~s}^{-1}\right)\end{array}$ & $\begin{array}{c}\mathrm{Gs} \\
\left(\mathrm{mol} \mathrm{H}_{2} \mathrm{O} \mathrm{m}^{-2} \mathrm{~s}^{-1}\right)\end{array}$ & EUW \\
\hline Catuai IAC62 & $1.85 \mathrm{a}$ & $0.05 \mathrm{a}$ & $2.17 \mathrm{~b}$ \\
Catuai IAC99 & $1.06 \mathrm{c}$ & $0.02 \mathrm{c}$ & $1.79 \mathrm{~b}$ \\
Ouro IAC4397 & $1.89 \mathrm{a}$ & $0.04 \mathrm{a}$ & $1.09 \mathrm{~b}$ \\
Tupi RN IAC1669-13 & $1.54 \mathrm{~b}$ & $0.03 \mathrm{~b}$ & $1.43 \mathrm{~b}$ \\
Obatã IAC1669-20 & $1.36 \mathrm{~b}$ & $0.03 \mathrm{~b}$ & $1.02 \mathrm{~b}$ \\
Mundo Novo IAC379-24 & $1.54 \mathrm{~b}$ & $0.03 \mathrm{~b}$ & $1.43 \mathrm{~b}$ \\
Mundo Novo IAC 388-17-2 & $2.44 \mathrm{a}$ & $0.05 \mathrm{a}$ & $2.14 \mathrm{~b}$ \\
Mundo Novo SH3 & $2.14 \mathrm{a}$ & $0.03 \mathrm{~b}$ & $0.44 \mathrm{~b}$ \\
Bourbon IACJ15 & $0.62 \mathrm{c}$ & $0.01 \mathrm{~d}$ & $5.78 \mathrm{a}$ \\
Icatu IAC 2944-11 & $0.55 \mathrm{c}$ & $0.01 \mathrm{~d}$ & $1.95 \mathrm{~b}$ \\
AO & 1.50 & 0.03 & 1.92 \\
CV (\%) & 52.45 & 40.74 & 0.0039 \\
p value & $<0.0001$ & $<0.0001$ & \\
\hline
\end{tabular}

AO: Average overall; CV: coefficient of variation.

According to stomatal conductance averages, the varieties Catuai IAC $62\left(0.05 \mathrm{mmol} \mathrm{CO}_{2} \mathrm{~m}^{-2} \mathrm{~s}^{-1}\right)$; Mundo Novo IAC 388-17-2 (0.05 mmol $\left.\mathrm{CO}_{2} \mathrm{~m}^{-2} \mathrm{~s}^{-1}\right)$ and Ouro IAC4397 (0.04 mmol $\left.\mathrm{CO}_{2} \mathrm{~m}^{-2} \mathrm{~s}^{-1}\right)$ had superior results standing out when comparing with the varieties Catuai IAC99 (0.02 mmol CO $\left.\mathrm{m}^{-2} \mathrm{~s}^{-1}\right)$, Bourbon IACJ15 (0.01 $\left.\mathrm{mmol} \mathrm{CO} \mathrm{m}^{-2} \mathrm{~s}^{-1}\right)$, and IAC 2944-11 (0.01 $\mathrm{mmol} \mathrm{CO}_{2} \mathrm{~m}^{-2}$ $\left.\mathrm{s}^{-1}\right)$ that had low values of this characteristic.
For efficient water use, the Bourbon IACJ15 variety had the highest result, standing out mainly when compared to the Mundo Novo SH3 variety that presented the lowest value of this trait. It is worth mentioning that the high variation coefficient of the parameter efficient water use, occurred due to the application of the formula that in some cases the average values of some plants were negative, indicating that the plant had closed stomata. 
According to the results obtained (Table 4) of phloem diameter, the varieties Catuai IAC62 (7.40) and Tupi RN IAC1669-13 (6.54) presented the best values, differing statistically from the other cultivars.

The variety Catuaí Vermelho IAC99 stood out in terms of thickness of adaxial epidermis and thickness of abaxial epidermis.

Analyzing the palisade parenchyma thickness of coffee cultivars, it was observed that the varieties IAC4397, Mundo Novo IAC379-24 and Mundo Novo SH3 presented the lowest results for this variable, being characterized as cultivars that have low thickness of this parenchyma.
Figure 1 shows the internal leaf morphology of coffee plant cultivars, where all the main.

Figure 2 shows the correlogram between the variables evaluated in the Arabica coffee varieties.

Table 4 shows the significant linear regressions after Pearson's correlation analysis. It is worth noting the positive correlations between the rate of $\mathrm{CO}_{2}$ assimilation (A) with stomatal conductance (gs) and efficient water use (EUW) and negatively with the yields of benefited grains (YGB). A positive correlation was observed between the xylem diameter of the leaves (XDL) with the efficient use of water (EUW).

Table 4. Average values of phloem diameter of leaf (PDL); xylem diameter of leaf (XDL); thickness of adaxial epidermis (TADE); thickness of abaxial epidermis (TABE) and thickness of palisade parenchyma (PP) of arabica coffee varieties.

Tabela 4. Valores médios do diâmetro foliar do floema (PDL); diâmetro do xilema da folha (XDL); espessura da epiderme adaxial (TADE);

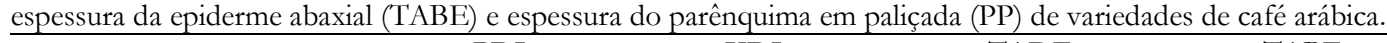

\begin{tabular}{|c|c|c|c|c|c|}
\hline & $\begin{array}{l}\text { PDL } \\
(\mu \mathrm{m})\end{array}$ & $\begin{array}{l}\text { XDL } \\
(\mu \mathrm{m})\end{array}$ & $\begin{array}{l}\text { TADE } \\
(\mu \mathrm{m})\end{array}$ & $\begin{array}{l}\text { TABE } \\
(\mu \mathrm{m})\end{array}$ & $\begin{array}{c}\mathrm{PP} \\
(\mu \mathrm{m})\end{array}$ \\
\hline Catuai A IAC62 & $7.40 \mathrm{a}$ & $12.30 \mathrm{a}$ & $24.55 c$ & $16.39 \mathrm{~b}$ & $38.95 \mathrm{a}$ \\
\hline Catuai V IAC99 & $5.82 \mathrm{~b}$ & $12.93 a$ & $29.12 \mathrm{a}$ & $18.30 \mathrm{a}$ & $43.98 \mathrm{a}$ \\
\hline Ouro A IAC4397 & $5.57 \mathrm{~b}$ & $12.68 \mathrm{a}$ & $26.06 b$ & $16.11 b$ & $35.15 b$ \\
\hline Tupi RN IAC1669-13 & $6.54 \mathrm{a}$ & $11.96 a$ & $25.13 \mathrm{c}$ & $15.64 \mathrm{c}$ & $43.17 \mathrm{a}$ \\
\hline Obatã V IAC1669-20 & $5.72 b$ & $12.17 \mathrm{a}$ & $28.02 \mathrm{a}$ & $14.68 \mathrm{c}$ & $39.78 \mathrm{a}$ \\
\hline Mundo Novo IAC379-24 & $5.69 \mathrm{~b}$ & $11.63 \mathrm{~b}$ & $22.76 c$ & $14.06 \mathrm{c}$ & $35.47 \mathrm{~b}$ \\
\hline $\begin{array}{l}\text { Mundo Novo IAC 388-17- } \\
2\end{array}$ & $5.33 \mathrm{~b}$ & $11.05 \mathrm{~b}$ & $24.63 c$ & $15.44 c$ & $39.25 a$ \\
\hline Mundo Novo SH3 & $5.34 \mathrm{~b}$ & $11.12 \mathrm{~b}$ & $27.38 b$ & $14.80 \mathrm{c}$ & $37.39 \mathrm{~b}$ \\
\hline Bourbon A IACJ15 & $5.49 \mathrm{~b}$ & $13.27 \mathrm{a}$ & $27.06 \mathrm{~b}$ & $13.98 \mathrm{c}$ & $41.46 \mathrm{a}$ \\
\hline Icatu Amarelo IAC2944-11 & $5.68 b$ & $9.93 \mathrm{~b}$ & $24.19 \mathrm{c}$ & $14.57 \mathrm{c}$ & $40.11 \mathrm{a}$ \\
\hline AO: & 5.86 & 11.91 & 25.89 & 15.40 & 39.47 \\
\hline $\mathrm{CV} \%$ & 31.28 & 24.75 & 13.74 & 23.92 & 20.27 \\
\hline $\mathrm{p}$ value & 0.0006 & 0.0009 & $<0.0001$ & 0.0004 & 0.0002 \\
\hline
\end{tabular}

AO: Average overall; CV: coefficient of variation.

Table 5. Matrix of significant linear regressions of Pearson's significant interactions of the variables analyzed in Arabica coffee varieties. Tabela 5. Matriz de regressões lineares significativas das interações significativas de Pearson com as variáveis analisadas nas variedades de café Arábica.

\begin{tabular}{llll}
\hline & $\mathrm{Y}=\beta_{\mathrm{O}}+\beta \mathrm{i}$ & $\mathrm{p}$ value & $\mathrm{R}^{2}$ \\
\hline $\mathrm{A}$ & $\mathrm{ci}=\mathrm{y}=316.725374-9.28721405 \mathrm{~A}$ & 0.0156 & 0.0447 \\
& $\mathrm{gs}=0.03047777+0.00222655 \mathrm{~A}$ & 0.0104 & 0.0546 \\
& $\mathrm{EUW}=0.81264382+0.63532586 \mathrm{~A}$ & $<0.0001$ & 0.1950 \\
$\mathrm{ci}$ & $\mathrm{YGB}=34.4246494-1.20554625 \mathrm{~A}$ & 0.0305 & 0.0351 \\
$\mathrm{E}$ & $\mathrm{EUW}=4.48081086-0.00849324 \mathrm{ci}$ & 0.0023 & 0.0672 \\
& $\mathrm{gs}=0.00609816+0.01882156 \mathrm{E}$ & $<0.0001$ & 0.7630 \\
$\mathrm{Gs}$ & $\mathrm{EUW}=3.80820229-1.24979977 \mathrm{E}$ & $<0.0001$ & 0.1476 \\
$\mathrm{XDL}$ & $\mathrm{EUW}=3.13032152-34.9177823 \mathrm{gs}$ & 0.0104 & 0.0535 \\
TABE & $\mathrm{EUW}=-1.5058922+0.29039981 \mathrm{XDL}$ & 0.0020 & 0.0725 \\
TADE & YGB $=43.0950005-0.69946628 \mathrm{TABE}$ & 0.0310 & 0.0388 \\
& YAB $=50.2769198-0.68814269 \mathrm{TADE}$ & 0.0499 & 0.0150 \\
\hline
\end{tabular}

\section{DISCUSSION}

Table 2 shows the variation in yield of the cultivars analyzed in this research. This phenomenon can be explained by the ability of the coffee culture, when the production is proportional to the number of knots or buds formed in the previous growing season, with high yields alternating with low yields (NOGUEIRA and TRUGO, 2003). This is an important characteristic for the genetic improvement of plants, as it seeks to develop varieties with higher yields and with little temporal variation. Varieties like Catuai amarelo IAC62, Catuai vermelho IAC99 and Ouro IAC4397 are undesirable in the coffee market from the productive point of view, as they presented low yield.

Plant transpiration is a component of the energy balance that determines leaf temperature, according to anatomical factors of the leaves, environmental factors and biological factors that determine the number and distribution of stomata (LEUZINGER et al., 2010). According to Nunes et al. (1968), the increase in leaf temperature may contribute to a certain reduction in the values of stomatal conductance and liquid photosynthesis rates, however, in this research, the influence of increased breathing was not observed causing a decrease in stomatal conductance.

Low stomatal conductance values lead to less $\mathrm{CO}_{2}$ inflow into the chloroplasts causing reductions in photosynthetic rates. The decrease in stomatal conductance ( $\mathrm{gs}$ ) indicates that photosynthesis would not be restricted by stomatal closure, nor by the concentration of $\mathrm{CO}_{2}$ within the substomatal chamber, but by other biochemical factors that would be making it difficult to reduce the $\mathrm{CO}_{2}$ there (Marur and Faria, 2008). The functioning of the stomata constitutes a physiological compromise because, when opened, they 
allow the assimilation of $\mathrm{CO}_{2}$ and the loss of $\mathrm{H}_{2} \mathrm{O}$. Closing, it reduces the entry of $\mathrm{CO}_{2}$ to the rubisco carboxylation sites inside the chloroplasts and conserves $\mathrm{H}_{2} \mathrm{O}$, reducing the risk of dehydration (TATAGIBA et al., 2015).
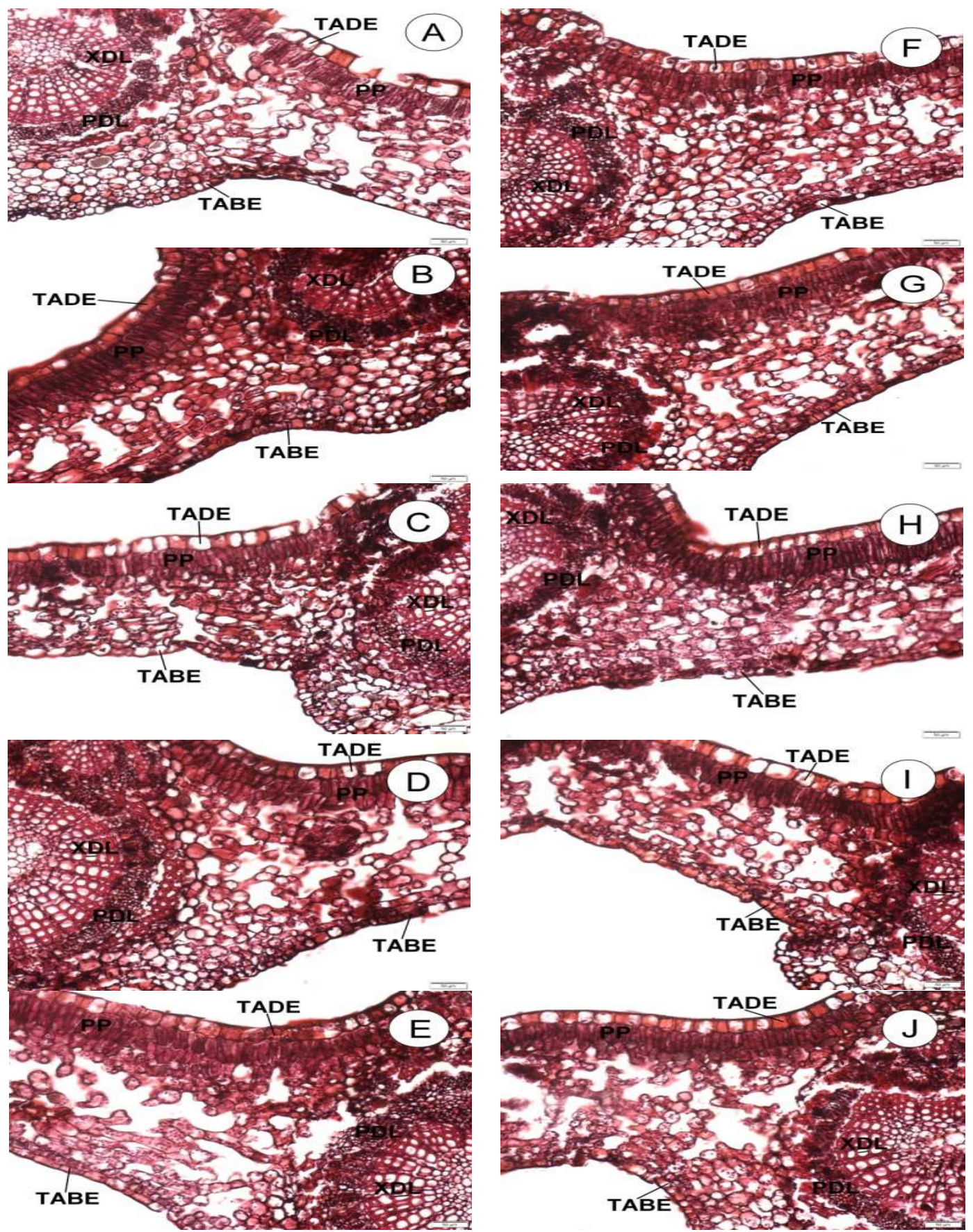

Figure 1. Internal leaf morphology of arabica coffee varieties. A: Catuai A IAC62; B: Catuai V IAC99; C: Ouro A IAC4397; D: Tupi RN IAC1669-13; E: Obatã V IAC1669-20; F: Mundo Novo IAC379-24; G: Mundo Novo IAC 388-17-2; H: Mundo Novo SH3 Faz São José; I: Bourbon A IACJ15 and J: Icatu Amarelo IAC 2944-11.

Figura 1. Morfologia interna da folha de variedades de café arábica. A: Catuai A IAC62; B: Catuai V IAC99; C: Ouro A IAC4397; D: Tupi RN IAC1669-13; E: Obatã V IAC1669-20; F: Mundo Novo IAC379-24; G: Mundo Novo IAC 388-17-2; H: Mundo Novo SH3 Faz São José; I: Bourbon A IACJ15 e J: Icatu Amarelo IAC 2944-11.

Among the physiological characteristics, which can be explored in breeding programs, the efficiency of water use stands out for nematode tolerance in conditions of water deficiency (SILVA et al., 2013). According to the results obtained with respect to the aforementioned variable, the Bourbon IACJ15 variety is promising for future breeding programs aimed at tolerance to nematode attack. The efficiency of water use corresponds to the amount of carbon fixed during photosynthesis for each water molecule lost during this process, therefore, the control of stomatal opening and closing is important to avoid excessive loss of water in transpiration, allowing the use of $\mathrm{CO}_{2}$ accumulated in sub-stomatal chambers and reducing water loss under water deficit conditions (TAIZ et al., 2017). This trait of 
Lisboa et al.

plants is a variable of relevant importance, as it reflects the irregular distribution, as well as water ability of the crop to tolerate conditions of low rainfall and accumulation (PERAZZO et al., 2013).

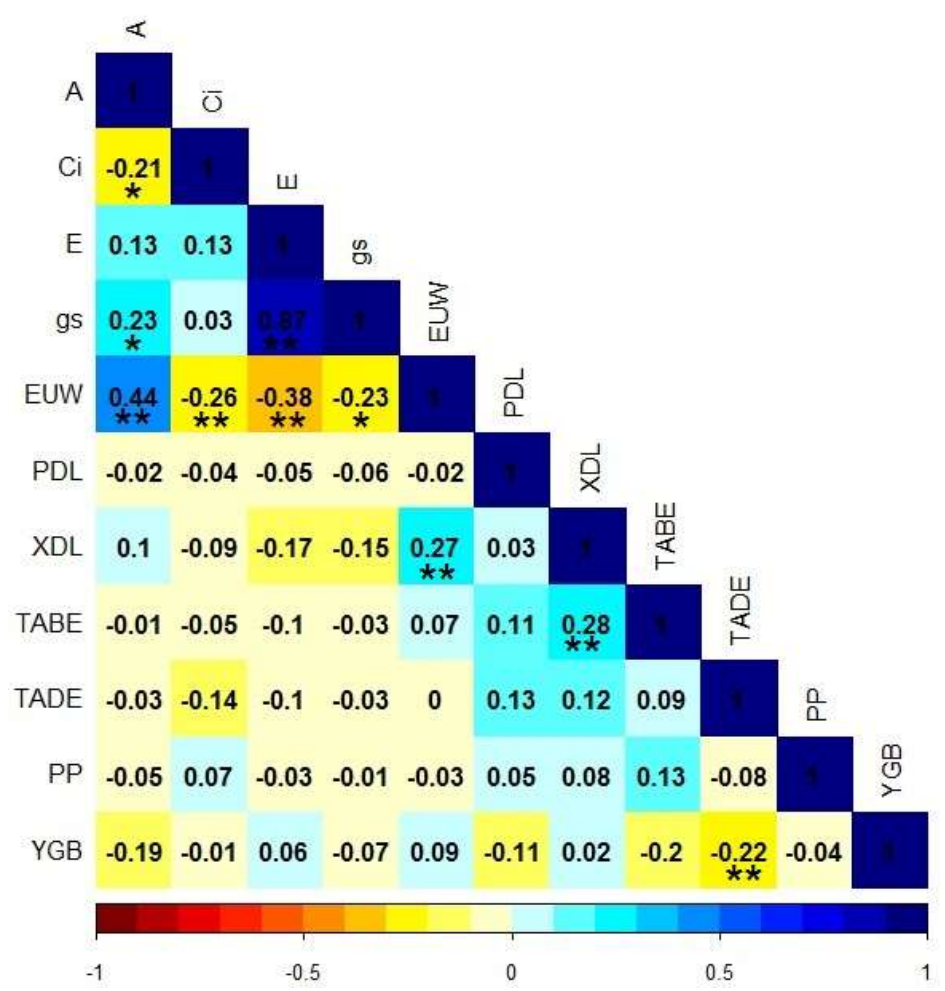

Figure 2: Pearson's correlations between the variables evaluated in Arabica coffee varieties.; A: rate of photosynthesis; Ci: internal $\mathrm{CO}_{2}$ concentration in the substomatal chamber; E: Transpiration; gs: Stomata conductance; EUW: Efficient use of water. PDL: phloem diameter of leaf; XDL: xylem diameter of leaf; TADE: thickness of adaxial epidermis; TABE: thickness of abaxial epidermis; PP: thickness of palisade parenchyma (PP) and YGB: yield of grains benefited.

Figura 2: Correlações de Pearson entre as variáveis avaliadas nas variedades de café arábica. A: taxa de fotossíntese; Ci: concentração interna de $\mathrm{CO}_{2}$ na câmara subestomática; E: Transpiração; gs: condutância estomática; EUW: Uso eficiente da água. PDL: diâmetro do floema da folha; XDL: diâmetro do xilema da folha; TADE: espessura da epiderme adaxial; TABE: espessura da epiderme abaxial; PP: espessura do parênquima paliçádico (PP) e YGB: rendimento de grãos beneficiado.

The efficiency of water use in plants is directly related to the functioning of the stomatal apparatus, since it corresponds to the ratio between the amount of $\mathrm{CO}_{2}$ assimilated and the amount of water transpired by the plant. In the case of C3 plants, as is the coffee plant, stomatal resistance causes a decrease in the photosynthetic rate due to the high $\mathrm{CO}_{2}$ compensation point for this group of plants (TAIZ et al., 2017).

Regarding the results of the phloem diameter, changes in phloem in terms of diameter, quantity, vessel area and other factors significantly influence photosynthesis, growth and development. When the plant has a more evolved xylem or in greater numbers, the supply of unprocessed sap supplied to the leaves of the plant canopies becomes more efficient, which does not compromise its physiological parameters. Thus, phloem also starts to perform more efficiently its distribution of sap elaborated to the other parts of the plant, thus being able to guarantee greater productivity (Castro et al., 2009).

Carvalho et al. (2001) evaluating the morphological aspects of Catuai Vermelho showed greater thickness of the leaves of Catuaí Vermelho with greater values of thickness of the epidermis and palisade and lacunous parenchyma. The authors found that the thickness of the abaxial and adaxial epidermis, and the palisade and lacunous parenchyma, contributed to the greater total leaf thickness. The data corroborate with that obtained in this research since this cultivar obtained the highest values of thickness of adaxial epidermis, thickness of abaxial epidermis and thickness of palisade parenchyma.

The greater thickness of the palisade parenchyma, which is a tissue rich in chloroplasts and the main tissue related to photosynthesis, can therefore favor the growth and development of plants (CASTRO et al., 2009). The higher values for the palisade parenchyma can give a greater photosynthetic capacity to the genotypes that exhibit them, being a favorable factor in conditions of high incident radiation (RIBEIRO et al., 2012).

The results of the positive correlations between the rate of $\mathrm{CO}_{2}$ assimilation (A) with stomatal conductance $(\mathrm{gs})$ and efficient water use (EUW) and negatively with the yields of benefited grains (YGB) were already expected, because with the increase in the $\mathrm{CO}_{2}$ assimilation rate, the stomatal conductance (gs) increased, which implied a greater opening of the stomatal cleft and thus provided a greater gas exchange, thus increasing the efficient use of water (EUW), as it required less amount of water to fix more $\mathrm{CO}_{2}$. Therefore, when a lower $\mathrm{CO}_{2}$ assimilation rate occurs, it reduces the grain yield (BELLASIO et al., 2017).

A positive correlation between the xylem diameter of the leaves (XDL) with the efficient use of water (EUW) which was already expected, because with the increase in the 
diameter of the vessels, there is a greater transport and availability of unprocessed sap for the leaves (Pfautsch et al., 2015; Brodersen, 2016). It is clear that the thickness of the epidermis (TABE and TADE) had a negative influence on the production of processed grains (YGB) demonstrating that with a greater thickness it can influence the passage of light beams until reaching the chloroplasts present in the palisade parenchyma (PP), o may have caused a lower rate of photosynthesis than, consequently, yield, as this correlation between AxYGB was also observed as mentioned previously.

\section{CONCLUSIONS}

The Arabica coffee variety Mundo Novo IAC 388-17-2 shows higher productivity of grain bags benefited in the seventh year of cultivation.

Variety of Bourbon IACJ15 coffee presented water use efficiency (EUW) which did not reflect in higher productivity.

The Catuai V IAC99 arabica coffee variety stood out in the internal morphology of the leaves.

The thickness of the adaxial and abaxial epidermis (TADE and TABE) and the $\mathrm{CO}_{2}$ assimilation rate (A) showed negative correlations with the productivity of processed coffee bags.

\section{REFERENCES}

AGRIANUAL. Anuário da agricultura Brasileira. São Paulo: FNP: Consultoria Andamp, Comércio, 2015. 497 p.

BANZATTO, D. A.; KRONKA, S. N. Experimentação Agrícola. 4 ed. São Paulo: Funep, 2013. 237p.

BELLASIO, C.; QUIRK, J.; BUCKLEY, T. N., AND DAVID J. BEERLINGA, D. J. A Dynamic hydromechanical and biochemical model of stomatal conductance for $\mathrm{C}_{4}$ photosynthesis. Plant Physiology, v. 175, p. 104-119, $2017 . \quad$ DOI: https://doi.org/10.1104/pp.17.00666

BRODERSEN, C. R. Finding support for theoretical tradeoffs in xylem structure and function. New Phytologist, v. 209, n. 1, p.8-10, 2016. DOI: https://doi.org/10.1111/nph.13763

CARVALHO, L. M. D.; SILVA, E. A. M. D.; AZEVEDO, A. A.; MOSQUIM, P. R.; CECON, P. R. Aspectos morfofisiológicos das cultivares de cafeeiro CatuaíVermelho e Conilon. Pesquisa Agropecuária Brasileira, Brasília, v. 36, n. 3, p. 411-416, 2001. DOI: https://doi.org/10.1590/S0100-204X2001000300003

CASTRO, E. M.; PEREIRA, F. J.; PAIVA, R. Histologia vegetal: estrutura e função de órgãos vegetativos. Lavras: UFLA, 2009. 234p.

EMPRESA BRASILEIRA DE PESQUISA AGROPECUÁRIA - EMBRAPA. Sistema brasileiro de classificação de solos. 3 ed. Brasília: Embrapa, 2013. $353 \mathrm{p}$.

KRAUS, J. E.; ARDUIM, M. Manual básico de métodos em morfologia vegetal. Seropédica: EDUR, 1997. 221p.

LEUZINGER, S.; VOGT, R.; KÖRNER, C. Tree surface temperature in an urban environment. Agricultural and Forest Meteorology, Amsterdam, v. 150, p. 56-62, 2010. DOI: https://doi.org/10.1016/j.agrformet.2009.08.006

MARUR, C. J.; FARIA, R. T. Photosynthesis of individual leaves in a coffee plant. Acta Scientiarium. Agronomy,
Maringá, v. 28, n. 3, p. 331-335, 2008. DOI: https://doi.org/10.4025/actasciagron.v28i3.941

NOGUEIRA, M.; TRUGO, L.C. Distribuição de isômeros de ácido clorogênico e teores de cafeína e trigonelina em cafés solúveis brasileiros. Revista Ciência e Tecnologia de Alimentos, Campinas, v. 23, n. 2, p. 296-299, 2003. DOI: $\quad$ https://doi.org/10.1590/S010120612003000200033

NUNES, M. A.; BIERHUIZEN, J. F.; PLOEMAN, C. Studies on productivity of coffee. I. Effect of light, temperature and $\mathrm{CO}_{2}$ concentration on photosynthesis of Coffea arabica. Acta Botanica Neerlandica, v. 17, p. 93-102, 1968. DOI: https://doi.org/10.1111/j.14388677.1968.tb00109.x

PFAUTSCH, S.; JUSTINE RENARD, J.; TJOELKER, M. G.; SALIH, A. Phloem as capacitor: radial transfer of water into xylem of tree stems occurs via symplastic transport in ray parenchyma. Plant Physiology, v. 167, p. 963-971, 2015. DOI: https://doi.org/10.1104/pp.114.254581

PINOTTI, E. B.; BARBOSA, R. Z.; ARAÚJO, H. M.; PERÃO, G. H. Utilização do estresse hídrico induzido no cafeeiro (Coffea arabica). Revista Científica Eletrônica de Agronomia, v. 7, n. 15, p. 1-8, 2009.

PERAZZO, A. F.; SANTOS, E. M.; PINHO, R. M. A.; CAMPOS, F. S.; RAMOS, J. P. D. F.; AQUINO, M. M. D.; BEZERRA, H. F. C. Características agronômicas e eficiência do uso da chuva em cultivares de sorgo no semiárido. Ciência Rural, Santa Maria, v. 43, n. 10, p .1771-1776, 2013. DOI: https:/ / doi.org/10.1590/S010384782013001000007

QUEIROZ-VOLTAN, R. B.; NARDIN, C. F.; FAZUOLI, L. C.; BRAGHINI, M. T. Caracterização da anatomia foliar de cafeeiros arábica em diferentes períodos sazonais. Revista Biotemas, v. 27, n. 4, p. 1-10, 2014. DOI: https://doi.org/10.5007/2175-7925.2014v27n4p1

RAIJ, B.; CANTARELLA, H.; QUAGGIO, J. A.; FURLANI, A. M. C. Recomendações de adubação e calagem para o Estado de São Paulo. 2 ed. Campinas: IAC, 1996. 285p.

RENA, A. B.; MALAVOLTA, E.; ROCHA, M.; YAMADA, T. Cultura do cafeeiro: fatores que afetam a produtividade. Piracicaba: Esalq, 1986. 447p.

RIBEIRO, M. D. N. O.; CARVALHO, S. P. D.; PEREIRA, F. J.; CASTRO, E. M. D. Anatomia foliar de mandioca em função do potencial para tolerância à diferentes condições ambientais. Revista Ciência Agronômica, v. 43, n. 2, p. 354-361, 2012. DOI: https://doi.org/10.1590/S1806-66902012000200019

SANTINATO, R.; FERNANDES, A. L. T.; FERNANDES, D. R. Irrigação na cultura do café. O lutador, 2 ed. Belo Horizonte: O Lutador, 2008. 476p.

SILVA, F. de A. S.; AZEVEDO, C. A. V. de. The Assistat Software Version 7.7 and its use in the analysis of experimental data. African Journal Agriculture Research, v. 11, n. 39, p. 3733-3740, 2016. DOI: http://dx.doi.org/10.5897/AJAR2016.11522

SILVA, P. E. M.; CAVATTE, P. C.; MORAIS, L. E.; MEDINA, E. F.; DAMATTA, F. M. The functional divergence of biomass partitioning, carbon gain and water use in Coffea canephora in response to the water supply: implications for breeding aimed at improving drought tolerance. Environmental and Experimental 
Lisboa et al.

Botany, v. 87, p. 49-57, 2013. DOI: https://doi.org/10.1016/j.envexpbot.2012.09.005

TAIZ, L.; ZEIGER, E.; MOLLER, I., M.; MURPHY, A. Fisiologia e desenvolvimento vegetal. 6 ed. Porto Alegre: Artmed, 2017. 858p.

TATAGIBA, S. D.; PEZZOPANE, J. E. M.; REIS, E. F. Fotossíntese em Eucalyptus sob diferentes condições edafoclimáticas. Engenharia na Agricultura, Viçosa, v. 23; n. 4, p. 336-345, 2015. DOI: https://doi.org/10.13083/14143984/reveng.v23n4p336-345 